OPEN ACCESS

Edited by:

Luis Puigjaner,

Universitat Politecnica de Catalunya,

Spain

Reviewed by:

Ahmed Rezk,

Aston University, United Kingdom

Rajesh S. Kempegowda,

Inrigo As, Norway

*Correspondence:

Kurt A. Rosentrater

Karosent@iastate.edu

Specialty section:

This article was submitted to

Process and Energy Systems

Engineering,

a section of the journal

Frontiers in Energy Research

Received: 18 March 2021

Accepted: 17 June 2021

Published: 10 August 2021

Citation:

Shafinas Muhammad NI and Rosentrater KA (2021) Economic Evaluation of Combined Heat and Power Integrated With Food Waste-

Based Ethanol Production.

Front. Energy Res. 9:682609.

doi: 10.3389/fenrg.2021.682609

\section{Economic Evaluation of Combined Heat and Power Integrated With Food Waste-Based Ethanol Production}

\author{
Noor Intan Shafinas Muhammad ${ }^{1,2}$ and Kurt A. Rosentrater ${ }^{1 *}$ \\ ${ }^{1}$ Agricultural and Biosystems Engineering Department, lowa State University, Ames, IA, United States, ${ }^{2}$ Faculty of Civil \\ Engineering Technology, Universiti Malaysia Pahang, Kuantan, Malaysia
}

The concern of food waste (FW) impact on the environment, societies, and economies, has triggered many researchers to find alternative ways to utilize these materials. FW can be high in glucose and other sugars (depending upon the food used) and has the potential to be converted into value-added products such as ethanol. Ethanol is an organic material that has a high demand from different industries for products such as fuel, beverages, pharmaceuticals, and other industrial applications. FW fermentation to produce ethanol may be a promising method, and might results in positive impacts on economies. However, it is a challenge for the product price to compete with that of corn ethanol due to low yield and the inconsistency of FW composition. Thus, to increase the profitability, a conventional fermentation plant integrated with a combined heat and power (CHP) system might be a great combination, and was analyzed in this study. Solid waste stream from the process can be converted into energy and could reduce the utility cost. Therefore, the main focus of this study is to evaluate the economic impact of this integrated system by estimating the minimum selling price (MSP) using techno-economic analysis (TEA) and compare to conventional plants without CHP. Results from this analysis showed that the MSE value for this integrated system was $\$ 1.88$ per gallon ( $\$ 0.50$ per liter). This study suggests that an integrated system with CHP was found to be more economical and attractive to be implemented on a commercial scale.

Keywords: food waste, ethanol, CHP (combined heat and power), techno-economic analysis, biofuel, industrial fermentation

\section{INTRODUCTION}

Every year, the world generates about 1.3 billion tons of food waste (FW) through supply food chain stages including at the consumer level. In addition to that, this waste is expected to increase due to several factors such as managerial and technical limitation, global population, modernization, and living style (Gustavsson et al., 2011; Aschemann-Witzel et al., 2015). In the United States, 76.1\% of the FW will be sent to the landfills as a final destination (EPA 2018). Furthermore, FW could lead to various problems such as to the environment, society, the ecosystem, and the economy (Papargyropoulou et al., 2014).

Prevention is the best option in the FW management hierarchy, followed by recycling, energy recovery, and disposal. Thus, by considering the amount of valuable nutrients in the FW, recycling using the biological platform in producing other value-added products would be a great approach. This method is expected to have a good impact on the economy and the environment compared to the thermochemical technology. 


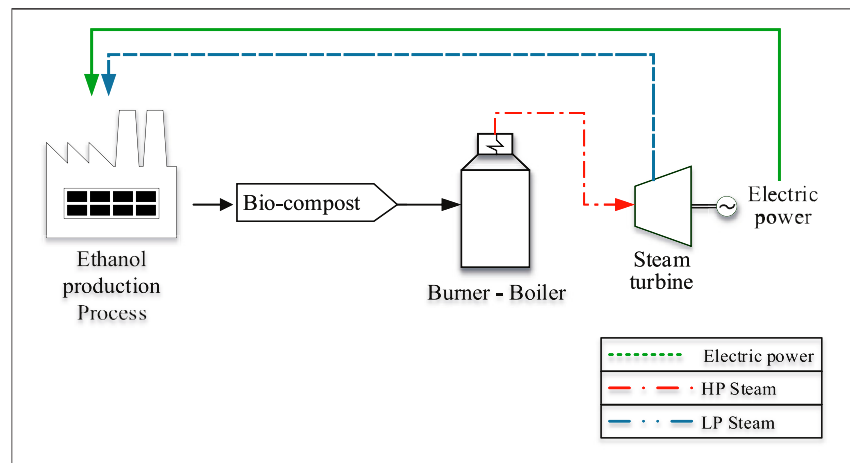

FIGURE 1 | Combined heat and power (CHP) schematic diagram.

Anaerobic digestion $(\mathrm{AD})$ and fermentation are relatively a matured technology that could produce energy such as biogas and ethanol respectively. However, according to Pham et al., 2015, an AD method will add a negative impact on the environment and be more costly.

In a study performed by Shafinas and Rosentrater, ethanol conversion from FW fermentation without enzymes was shown to have good potential from an economic perspective. Even though the distillation column was identified as an energy-intensive process, the minimum selling price (MSP) value was the lowest compared to the membrane separation process. From the economic analysis, the MSE for FW fermentation without enzymes and 2-step distillation system was found to be $\$ 2.41 /$ gal (Muhammad and Rosentrater 2020a). This value is in between corn ethanol price and cellulosic ethanol. However, the ethanol price from FW fermentation is expected to be more economical if the production process could integrate with the combined heat process $(\mathrm{CHP})$ by producing insite energy to minimizing the utility cost.

$\mathrm{CHP}$ is an integrated system that could produce electric power and steam on site. The advantages of embedded on site the plant are to avoid losses in distribution and transportation from the electrical power grid. The CHP is not considered as technology, but a method in applying technologies. Therefore, the implementation of this system could increase energy efficiency, minimize the emission, reduce utility cost, and promote sustainable development. Various studies have been suggested to use the integrated system in the ethanol fermentation plant due to advantages as mentioned above (Daianova et al., 2012; Raj, Iniyan, and Goic 2011; Eriksson and Kjellström 2010; Dias, Lima, and Mariano 2018).

The concept of CHP is direct combustion of the solid waste stream that will convert chemical energy into heat energy. The consistent of the heat source from the boiler will turn water into high-pressure steam. By using the Rankine cycle principle, the steam turbine can produce electricity. The backpressure steam turbine is commonly used in the industrial plant because of the low capital cost, simple configuration, and high efficiency (DOE 2016). The steam exhausts from the system will be recovered and used directly to a process and steam distribution. The biomass moisture content of biomass should be in the range of $15-55 \%$ before it can be directly burnt in the combustion system (Pirouti et al., 2010). Details of the overall process are shown in the schematic diagram in Figure 1.

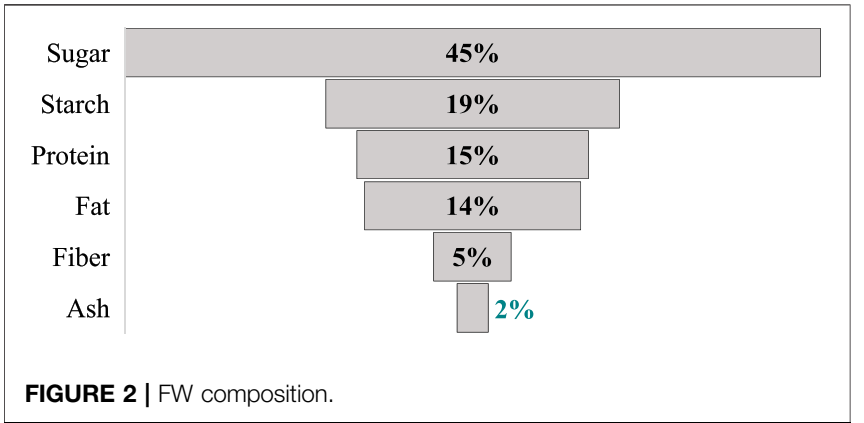

In this study, FW fermentation without enzymes integrated with the CHP process is modeled. The process model and conditions are similar to a study done by Muhammad and Rosentrater but with an additional energy cogeneration model (Muhammad and Rosentrater 2020b). The primary target of this study is to evaluate and compare the economic performance between with and without the integrated system. The technoeconomic analysis will be performed to estimate the minimum selling price (\$/gal) and compared with previous studies. The sensitivity analysis will be performed to identify the impact of the processing parameter on economic feasibility.

\section{METHODOLOGY}

\section{Process Modeling}

Figure 2 shows the FW composition used in this study. This information was based upon data collected in our laboratory. The fermentation process was modeled using anaerobic conditions without any hydrolysis enzymes added, and ethanol yield was set to $2.2 \%(\mathrm{w} / \mathrm{w})$ (based on laboratory results). The yield is considered higher compared to the previous study (Suwannarat and Ritchie 2015).

SuperPro Designer V9.0 software was used to simulate the integrated conceptual fermentation plant and evaluate the performance on a commercial scale. The daily plant feedstock is supposed to be $2000 \mathrm{Mg}$, and assuming no cost.

A 2-step distillation process was used to separate the ethanol from the fermentation broth followed by a purification process through a molecular sieve. The waste stream from this process was considered as a co-product that can be utilized as liquid fertilizer and bio-compost. Previous study found that by selling these co-products to other industries it could maximize the profit. (Muhammad and Rosentrater 2020a). However, in this study, bio compost was being utilized to generate heat and power by using the CHP system. The moisture content of bio compost was maintained at $40 \%$ by weight before being combusted in the burner. The chemical energy will be converted into heat energy to generate steam in the boiler. High-pressure steam turns the steam turbine which satisfies the thermodynamic cycle that changes heat to mechanical works. The turbine drives the generator and finally generates electric power and then will be used back in the facilities. In this study, assume that no surplus electricity can be sold to the grid. 


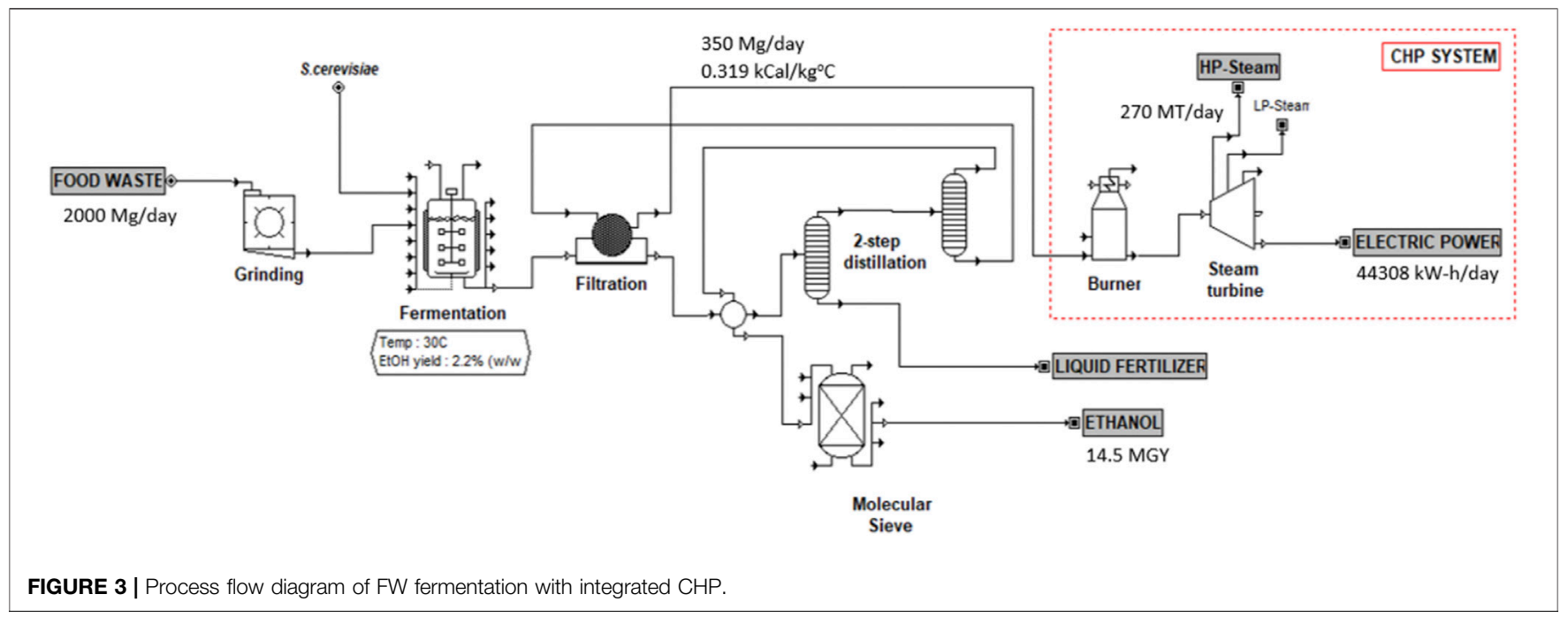

TABLE 1 | Detailed investment of CHP integrated with FW fermentation plant.

\begin{tabular}{lc}
\begin{tabular}{l} 
Assumption of investment Peters et al. (2003); Brown and Brown (2014) \\
\hline TPEC (Total Purchased
\end{tabular} & $\begin{array}{c}\text { Value estimate by SuperPro Simulation } \\
\text { (2018 dollars) }\end{array}$ \\
\hline $\begin{array}{l}\text { Purchased equipment } \\
\text { installation }\end{array}$ & $39 \%$ of TPEC \\
Instrument and control & \\
Piping & $26 \%$ of TPEC \\
Electrical system & $31 \%$ of TPEC \\
Building (including services) & $10 \%$ of TPEC \\
Yard improvements & $29 \%$ of TPEC \\
Services facilities & $12 \%$ of TPEC \\
TIEC (Total Installed Equipment & $55 \%$ of TPEC \\
Cost) & $202 \%$ \\
Indirect cost & \\
Engineering & \\
Construction & $32 \%$ of TPEC \\
Legal and contractors' fees & $24 \%$ of TPEC \\
TIC (Total Indirect Cost) & $23 \%$ of TPEC \\
Project Contingency & \\
FCl (Fixed Capital Investment) & $20 \%$ of TIC + TIEC \\
Non-depreciated Direct Cost & TIC + TIEC + Contingency \\
Working Capital & \\
Land & $15 \%$ of FCI \\
TPI (Total Project Investment) & $6 \%$ of TPEC \\
Lang Factor & FCl + WC + Land \\
& 5.46
\end{tabular}

Furthermore, the exhaust steam from the steam turbine will be captured and used for the heating system. The process diagram flow is illustrated in Figure 3.

The size and quantity of equipment, utilities and energy consumptions, transportation cost, labor, and raw material needed were determined by mass and energy balance from the simulation. The plant had 7,900 operating hours per year.

\section{Techno-Economic Assumptions}

Techno-economic analysis (TEA) is used to evaluate the economic viability of the CHP plant integrated with the FW based ethanol production plant. Equipment purchased cost was
TABLE 2 | Utility prices (EIA 2017).

\begin{tabular}{lc}
\hline Utility component & Prices \\
\hline Electricity $(\$ / \mathrm{kW}-\mathrm{h})$ & 5.5 \\
Water $(\$ / \mathrm{gal})(\$ / \mathrm{L})$ & $0.350(0.09)$ \\
Steam $(\$ / \mathrm{Mg})$ & 12.00 \\
Cooling water $(\$ / \mathrm{Mg})$ & 0.05 \\
Chilled water $(\$ / \mathrm{Mg})$ & 0.40
\end{tabular}

taken from the SuperPro Designer V9.0 software and indexed to 2018 dollars. The methodology to calculate the project investment expenditure was adopted from Peters et al., 2003. In addition to that, 3.02 installation factor was used as it is a common assumption factor for a biorenewable facilities plant. Discounted cash flow analysis spreadsheet was performed to estimate the MSE price ( $\$ / g a l)$ with predetermined internal rate of return to generate a net present value (NPV) of zero (Brown and Brown 2014). The IRR value was set to $10 \%$ to allow the ethanol product cost to have a competitive price in the market Most of the financial assumptions have been adapted from National Renewable Energy Laboratory Reports (NREL) (Wright et al., 2010; Tao et al., 2014). The main assumptions made in this study are listed below.

- Plant capacity: $2000 \mathrm{Mg} /$ day (t/day)

- Plant feedstock: FW with $78 \%$ moisture content

- Plant distance: $12 \mathrm{mi}(19.3 \mathrm{~km})$ radius (Poliafico and Murphy 2007)

- Plant life: $20 \mathrm{y}$

- Equity financed: $100 \%$

- The internal rate of return (IRR): $10 \%$ (Short, Packey, and Holt 1995)

- General plant depreciation: 7 y with $200 \%$ double declining balance (DDB)

- CHP plant depreciation: 20 y with $150 \%$ double declining balance (DDB) 
TABLE 3 | Assumptions for operator requirements for various types of process equipment (Brown and Brown 2014).

\begin{tabular}{lc} 
Equipment type & $\begin{array}{c}\text { Operators per unit per } \\
\text { shift }\end{array}$ \\
\hline Boilers & 1.0 \\
Electric generating plants & 3.0 \\
Crushers, mills, grinders & 1.0 \\
Evaporators & 0.2 \\
Furnace & 0.5 \\
Heat exchangers & 0.1 \\
Reactors/bioreactors & 0.5 \\
Clarifiers and thickeners & 0.2 \\
Mixers & 0.3 \\
Rotary and belt filters & 0.2 \\
Screens & 0.05
\end{tabular}

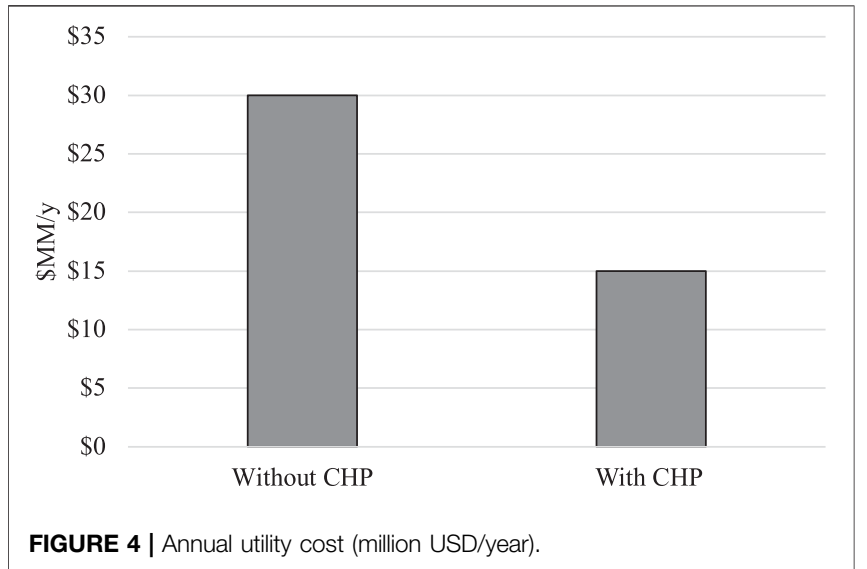

TABLE 4 | Sensitivity analysis parameters for FW fermentation process integrated with CHP.

\begin{tabular}{|c|c|c|c|}
\hline Parameters & Optimistic & Base case & Pessimistic \\
\hline Plant distance-miles radius (km radius) & $8(12.9)$ & $12(19.3)$ & $24(38.6)$ \\
\hline Plant Capacity- Mg/day & 1,000 & 2000 & 3,000 \\
\hline Liq. fertilizer resale value- $\$ / g a l(\$ / L)$ & $40(10.6)$ & $30(7.9)$ & $20(5.3)$ \\
\hline Ethanol yield $(\% \mathrm{w} / \mathrm{w})$ wet basis & 2.9 & 2.2 & 1.5 \\
\hline Fix capital cost $(\$ M M)$ & 407 & 585 & 757 \\
\hline
\end{tabular}

- CHP feedstock: bio compost with $40 \%$ moisture content

- Contingency factor: $20 \%$ from total installed equipment and indirect cost

- Construction period: 2.5 years with total capital investment spent with 8, 60 and 32\% for first, second and third year respectively.

- Startup period: 6 months with considering $50 \%$ of revenues, $75 \%$ variable cost and $100 \%$ fixed expenses will be achieved.

There were three major cost areas used in the discounted cash flow analysis to estimate MSE (\$/gal): Total projet investment (TPI), variabel cost ( $\$ / y)$ and the fixed operating cost $(\$ / y)$. The detailed investment costs are shown in Table 1 upon assumption.

Variable cost consists of the raw material cost, transportation cost, and utility cost. The utility cost depends on the energy balance of the whole process and the prices for each utulity component as shown in Table 2. The fixed cost consists of operating labor cost, laboratory cost, overhead, maintenance, local taxes, and insurances. The labor costs depend on the number of operators required per equipment, as listed in Table 3.

Economies of scale will be performed to evaluate the reduction of the product value while increasing daily feedstock volume from 10 to $5,000 \mathrm{Mg}$. From this analysis, the range of optimum feedstock value with the lower MSE value will be estimated for the future study.

\section{Sensitivity Analysis}

Further analysis is required to identify which parameter has the most significant impact on MSE value. A sensitivity analysis is a method used by modifying one parameter value while

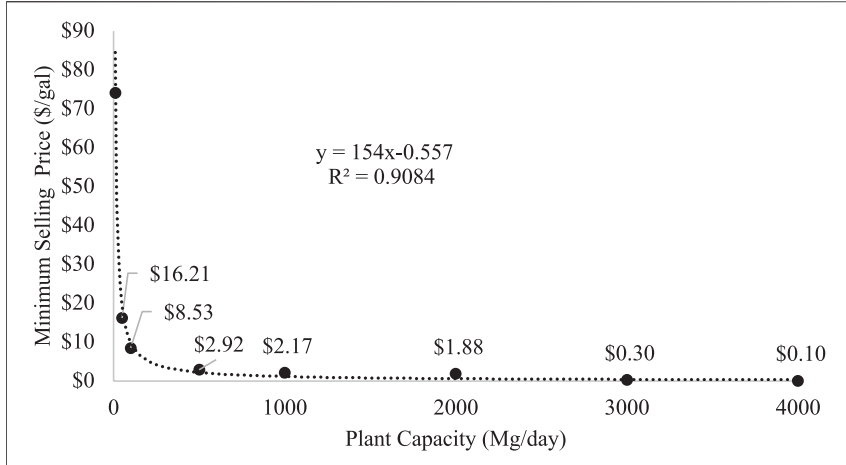

FIGURE 5 | Economies of scale for FW fermentation process integrated with $\mathrm{CHP}$.

maintaining others. Table 4 shows the sensitivity analysis parameters selected for this analysis. These parameters are identified as a powerful impact on plant economic performance.

\section{RESULTS AND DISCUSSION}

\section{Economic Analysis}

This plant is designed with $2000 \mathrm{Mg} /$ day of $\mathrm{FW}$ as a feedstock. The mass and energy balance was obtained from the simulation result. From the discounted cash flow analysis, the MSE price was estimated to $\$ 1.88$ per gallon ( $\$ 0.50$ per liter) with yielding an NPV of zero and $10 \%$ IRR. Results from this analysis reveals that the integrated process is found to be the most economical process 


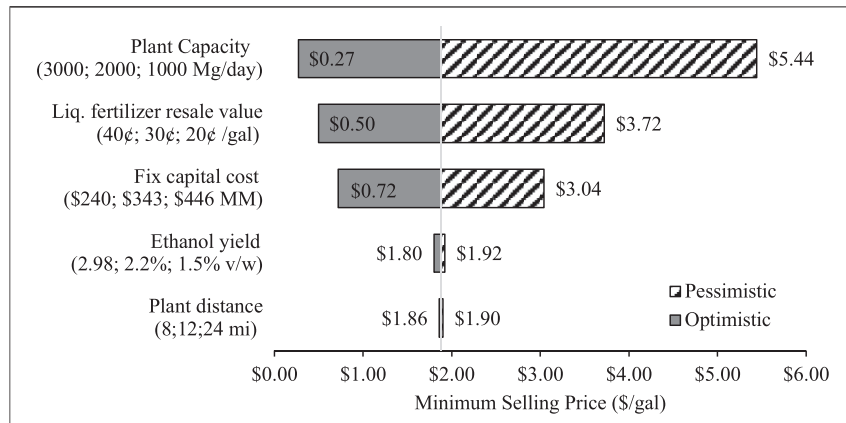

FIGURE 6 | Sensitivity analysis of FW fermentation process integrated with CHP (Optimistic is the best case scenario simulation, pessimistic is the worst case scenario simulation).

compared to the other studies from Muhammad (Muhammad 2019).

The CHP integrated plant has a value for total installed equipment cost (TIEC) and total project investment (TPI) of $\$ 221 \mathrm{MM}$ and $\$ 400 \mathrm{MM}$ respectively. In addition to that, the annual utility cost $(\$ / y)$ without credit power and heat from $\mathrm{CHP}$ was $\$ 30 \mathrm{MM}$ annually as detailed in Figure 4. However, this value reduces more than $50 \%$ by using energy generated from $\mathrm{CHP}$. This finding shows that the fermentation process integrated with CHP has a significant impact on reducing the product cost.

Economies of scale for this study are represented in Figure 5. From the graph, there is a power relationship of -0.557 between MSE and feedstock size. It also shows that with the feedstock rate varying between 10 and 4,000 Mg per day, the MSE of ethanol ranges from $\$ 74.16$ to $\$ 0.10$ per gallon of ethanol. The MSE keep decreasing because there is surplus of electricity that exceeds demand. Thus, it will be sold to the grid. However, higher feedstock capacity is impossible due to the logistic problem. FW is made up of organic materials that are easily contaminated by other organisms. Therefore, proper storage is required in a loading area. Therefore it will incur the cost of operation and is not economically viable.

\section{Sensitivity Analysis}

Figure 6 shows the sensitivity analysis for this study. From the tornado chart, it indicates that feedstock plant capacity is the most influential parameter in estimating the MSE value. Increasing the amount of FW feedstock to the plant from

\section{REFERENCES}

Aschemann-Witzel, J., de Hooge, I., Amani, P., Bech-Larsen, T., and Oostindjer, M. (2015). Consumer-Related Food Waste: Causes and Potential for Action. Sustainability 7 (6), 6457-6477. doi:10.3390/su7066457

Brown, R. C., and Brown, T. R. (2014). "Economics of Biorenewable Resources," in Biorenewable Resources Engineering New Products From Agriculture. 2nd ed. (Ames, Iowa: Wiley Blackwell), 307.

Daianova, L., Dotzauer, E., Thorin, E., and Yan, J. (2012). Evaluation of a Regional Bioenergy System with Local Production of Biofuel for Transportation, Integrated with a CHP Plant. Appl. Energ. 92, 739-749. doi:10.1016/ J.APENERGY.2011.08.016
$1,000 \mathrm{Mg} /$ day to $3,000 \mathrm{Mg} /$ day will decrease the value of MSE from $\$ 5.44$ to $\$ 0.27$ per gallon.

\section{CONCLUSIONS}

This techno-economic analysis evaluates the cost of integrated $\mathrm{CHP}$ with FW fermentation process in producing ethanol as the primary product. From the discussions above, waste stream can be converted into heat and power energy and utilized back to the process. This process could reduce the annual utilities cost by up to $50 \%$. The results from discounted cash flow analysis showed that the MSE value for an integrated system is lower compared to previous study as discussed above given by $\$ 1.88$ per gallon $(\$ 0.50$ per liter) and $\$ 2.41$ per gallon ( $\$ 0.64$ per liter) respectively. This finding would justify that integrated CHP with ethanol production plant is more economically attractive and more energy efficient.

Additionally, from the sensitivity analysis, results showed that the variability of feedstock plant capacity at $\pm 100 \%$ would give an MSE value in the range of $\$ 0.27$ to $\$ 5.44$ per gallon. Based on the economics of scale, the graph shows that the MSE value is decreasing when the feedstock plant capacity increases. As expected, it occurs because of surplus electricity which will be sold to the grid to improve profitability. However, a higher amount of feedstock will require an extensive storage facility which is not modeled in this study. Therefore, further optimization study is recommended to be done to find the optimal feedstock plant including the storage facilities. This information is one of the essential aspects for the investors and shareholders for future consideration.

\section{DATA AVAILABILITY STATEMENT}

The raw data supporting the conclusions of this article will be made available by the authors, without undue reservation.

\section{AUTHOR CONTRIBUTIONS}

NS conducted the research, conducted the analysis, and drafted the manuscript. KR conceived the project, provided supervision, and edited the manuscript.

Dias, M. O. S., Lima, D. R., and Mariano, A. P. (2018). “Techno-Economic Analysis of Cogeneration of Heat and Electricity and Second-Generation Ethanol Production from Sugarcane," in Advances In Sugarcane Biorefinery (London, UK: Elsevier), 197-212. doi:10.1016/B978-0-12804534-3.00010-0

DOE (2016). Combined Heat and Power Technology Fact Sheet Series. U.S. Department of Energy. Available at: https://www.energy.gov/sites/prod/files/ 2016/09/f33/CHP-SteamTurbine.pdf (Accessed July 01, 2020).

EIA (2017). Iowa State Energy Profile. U.S. Energy Information Administration. Available at: https://www.eia.gov/state/print.php?sid=IA (Accessed July 01, 2020).

EPA (2018). Advancing Sustainable Materials Management: 2015 Fact Sheet Assessing Trends in Material Generation, Recycling, Composting, Combustion 
with Energy Recovery and Landfilling in the United States. Available at: https:// www.epa.gov/sites/production/files/2018-07/documents/2015_smm_msw_ factsheet_07242018_fnl_508_002.pdf (Accessed July 01, 2020).

Eriksson, G., and Kjellström, B. (2010). Assessment of Combined Heat and Power (CHP) Integrated with Wood-Based Ethanol Production. Appl. Energ. 87 (12), 3632-3641. doi:10.1016/J.APENERGY.2010.06.012

Gustavsson, J., Cederberg, C., Sonesson, U., van Otterdijk, R., and Meybeck, A. (2011). Global Food Losses and Food Waste: Extent, Causes and Prevention. Rome, Italy. doi:10.1098/rstb.2010.0126

Muhammad, N. I. S. (2019). Comparative Assessment of the Economic and Environmental Impacts of Food Waste Fermentation on Value-Added Products. Graduate Theses and Dissertations Iowa State University. Available at: https://lib.dr.iastate.edu/etd/17063.

Muhammad, N. I. S., and Rosentrater, K. A. (2020a). Economic Assessment of Bioethanol Recovery Using Membrane Distillation for Food Waste Fermentation. Bioengineering 7 (1), 15. doi:10.3390/bioengineering7010015

Muhammad, N. I. S., and Rosentrater, K. A. (2020b). Techno-Economic Evaluation of Food Waste Fermentation for Value-Added Products. Energies 13 (2), 436. doi:10.3390/en13020436

Papargyropoulou, E., Lozano, R., K. Steinberger, J., Wright, N., and Ujang, Z. b. (2014). The Food Waste Hierarchy as a Framework for the Management of Food Surplus and Food Waste. J. Clean. Prod. 76, 106-115. doi:10.1016/ J.JCLEPRO.2014.04.020

Peters, M. S., Timmerhaus, K. D., and West, R. E. (2003). Plant Design and Economics for Chemical Engineers. 5th ed. Boston: McGraw-Hill.

Pham, T. P. T., Kaushik, R., Parshetti, G. K., Mahmood, R., and Balasubramanian, R. (2015). Food Waste-To-Energy Conversion Technologies: Current Status and Future Directions. Waste Manage. 38, 399-408. doi:10.1016/ J.WASMAN.2014.12.004

Pirouti, M., Wu, J., Ekanayake, J., and Jenkins, N. (2010). "Dynamic Modelling and Control of a Direct-Combustion Biomass CHP Unit," In 45th International Universities Power Engineering Conference UPEC2010, Cardiff, UK, 1-6.

Poliafico, M., and Murphy, J. D. (2007). Anaerobic Digestion in Ireland: Decision Support System. Ireland: Department of Civil, Structural and Environmental EngineeringCork Institute of Technology.
Raj, N. T., Iniyan, S., and Goic, R. (2011). A Review of Renewable Energy Based Cogeneration Technologies. Renew. Sustainable Energ. Rev. 15 (8), 3640-3648. doi:10.1016/J.RSER.2011.06.003

Short, W., Packey, D. J., and Holt, T. (1995). “A Manual for the Economic Evaluation of Energy Efficiency and Renewable Energy Technologies," in A Manual for the Economic Evaluation of Energy Efficiency and Renewable Energy Technologies (Golden, CO). doi:10.2172/35391

Suwannarat, J., and Ritchie, R. J. (2015). Anaerobic Digestion of Food Waste Using Yeast. Waste Manage. 42, 61-66. doi:10.1016/j.wasman.2015.04.028

Tao, L., Schell, D., Davis, R., Tan, E., Elander, R., and Bratis, A. (2014). “NREL 2012 Achievement of Ethanol Cost Targets: Biochemical Ethanol Fermentation via Dilute-Acid Pretreatment and Enzymatic Hydrolysis of Corn Stover," in NREL 2012 Achievement of Ethanol Cost Targets: Biochemical Ethanol Fermentation via Dilute-Acid Pretreatment and Enzymatic Hydrolysis of Corn Stover (United States: Golden, CO). doi:10.2172/1129271

Wright, M. M., Daugaard, D. E., Satrio, J. A., and Brown, R. C. (2010). TechnoEconomic Analysis of Biomass Fast Pyrolysis to Transportation Fuels. Fuel 89, S2-S10. doi:10.1016/J.FUEL.2010.07.029

Conflict of Interest: The authors declare that the research was conducted in the absence of any commercial or financial relationships that could be construed as a potential conflict of interest.

Publisher's Note: All claims expressed in this article are solely those of the authors and do not necessarily represent those of their affiliated organizations, or those of the publisher, the editors and the reviewers. Any product that may be evaluated in this article, or claim that may be made by its manufacturer, is not guaranteed or endorsed by the publisher.

Copyright (c) 2021 Shafinas Muhammad and Rosentrater. This is an open-access article distributed under the terms of the Creative Commons Attribution License (CC $B Y)$. The use, distribution or reproduction in other forums is permitted, provided the original author(s) and the copyright owner(s) are credited and that the original publication in this journal is cited, in accordance with accepted academic practice. No use, distribution or reproduction is permitted which does not comply with these terms. 